\title{
CROSSOLIPARIS - A NEW GENUS OF MALAXIDINAE (ORCHIDACEAE, MALAXIDEAE), FROM NEOTROPIC
}

\author{
HANNA B. MARGOŃSKA \\ Department of Plant Taxonomy and Nature Conservation, Gdańsk University \\ Al. Legionów 9, 80-441 Gdańsk, Poland \\ e-mail: dokhbm@univ.gda.pl
}

(Received: May 7, 2009. Accepted: August 24, 2009)

\begin{abstract}
A new genus Crossoliparis of the subtribe Malaxidinae (Orchidaceae), from tropical area of Central America is proposed. The new genus type species is described and illustrated. Keys to species of genus Crossoliparis and its close related genera of subtribe Malaxidinae from Americas, is added.
\end{abstract}

KEY WORDS: Americas, Crossoglossa, Crossoliparis, Liparis, Malaxidinae, Malaxis, Orchidaceae, taxonomy.

\section{INTRODUCTION}

As working on the taxonomic revision of the subtribe Malaxidinae (Orchidaceae), I had the occasion to study dried and liquid preserved herbarium specimens, living materials and pertinent bibliography at deposited in various collections. Among neotropic representatives of the subtribe one species was difficult to classification. Liparis wendlandii is a very specific orchid. H.G. Reichenbach (1866) described it amongst other as small plant with: pseudobulb, covered by few sheaths; leaf single (sometimes with additional smaller leaf), cuneate-ovate, apically acute; raceme subdense, few-flowered; bracts ligulate, obtuse at apices; sepals ligulate, obtuse at apices; petals linear; lip ligulate, minutely serrulate at margins, apically dilatate, basally a little bit auriculate, lamina convexity, longitudinal, narrowly triangular, broader near lip base. Gynostemium was noted as small, with abbreviate column, androclinium subquadrate, rostellum elongated, spathulate, stigma at limbate cavity, anther connective also elongate, obliquely triangular, pollinia parallel.

Reichenbach mentioned in protologue about resemblance of the species habit to African Liparis capensis Lindl. Lip lamina, in general outline is close to Liparis, only.

It is difficult to understand on the base of which characters Williams (1946) transferred the species to genus Malaxis Sol. ex Sw. He mentioned "seems to have most of the technical characters of Malaxis". Small size of plants, leaves character and presence of pseudobulb, short gynostemium, elongated rostellum might be only superficially similar to Malaxis (type-species: Mal. spicata Sol. ex Sw.).

Dodson (1993) placed Liparis wendlandii at Crossoglossa. The species, in fact, has like Crossoglossa e.g.: lip erect, denticulate margins, with basal auricles overlapping the gynostemium base and by prominent ring-like rim connected with it; basal calli bilaterally just near the rim, geminate and fold-like, lip lamina central keel longitudinal and convex.

However, wendlandii rhizomes are distinctly abbreviated, pseudobulb strongly developed, leaf usually one (rarely two), strongly elongated anther connective and rostellum, differently, stigma deep, erectly limbate, pollinia parallely situated to gynostemium column and covered only from above by anther locules and connective. The young shoot originates from base of previous, older pseudobulb and developes own pseudobulb when its leaf (rarer leaves) and inflorescense are already created.

Crossoglossa species always differ from wendlandii by e.g.: stem-like shoot, slightly swollen in the basal part, slender, elongated above, few-to tens-nodded, mostly covered by leaf petioles and sheaths, with leaves numerous, distichously distributed along whole stem; flowers usually very delicate, with tepals nearly translucent; gynostemium at least twice as long as anther; staminodia vey obscure, anther connective enlarged and broad, distally truncate or round, pollinia partly hidden in anther locules.

According to all above, neither Liparis, Malaxis or Crossoglossa are the right genus for wendlandii species. Therefore I propose a separate new genus for the species.

\section{KEY TO CROSSOLIPARIS AND CLOSELY RELATED TROPICAL AMERICAS GENERA OF SUBTRIBE MALAXIDINAE}

1a. Column of gynostemium massive, short, at most slightly longer than staminodes

1b. Column of gynostemium slender, elongate, at least two times longer than staminodes 
2a. Lip with trilobed epichyle, anther erect, subparallel to the gynostemium column; anther locules opening apically. Malaxis

2b. Lip with simple, one-lobed, at most distally dilatate epihyle, anther relatively large; anther locules opening apically ventrally

3a. Pseudobulb 1-nodded; leaf (rare two leaves) originates from the pseudobulb basal nodes; rostellum and anther connective over two times longer then anther length, narrow Crossoliparis

3b. Stem a few nodded; leaves distichously distributed along whole stem; rostellum abbreviate; anther connective never reaching the anther length, forming at most broad roof over the anter locules Crossoglossa

\section{CROSSOLIPARIS MARG. GEN. NOV.}

TYPE: Crossoliparis wendlandii (Rchb.f.) Marg. [=Liparis wendlandii Rchb.f.].

Plantae facie sectionis Liparis pseudotuberibus distinctis unifloris, floribus Corssoglossae similes labellis strictis pyriformibusque, basi callo annuloque praeditis, fascis centralibus toto labello longitudinaliter dispositis et marginibus irregulariter denticulatis; gynostemium diversum, inter alia perbreve, connectivo antherae longissimo, angusto recurvatove, rostello elongato, longitudinaliter incrassato, marginibus flexuosis.

Plants small, 3-6 cm high, caespitose (Fig. 1A). Rhizome distinctly abbreviated. Roots and new, young shoots appearing from the basal nodes of pseudobulb. Pseudobulbous $0.8-1.5 \mathrm{~cm}$ long, globular to ovoid, always covered by few sheaths (the external one fibrous) and leaf-bases. Leaf single (sometimes additional a second one, not fully developed), $0.9-2 \mathrm{~cm}$ long, $0.5-1.5 \mathrm{~cm}$ wide, ovate to oblong ovate, acute at the apex, distinctly cuneate at the base, distinctly petiolate. Inflorescence $2-5 \mathrm{~cm}$ tall; raceme ca. 1-2 cm long, 5-20-flowered, dense to subdense. Floral bracts $0.3-0.4 \mathrm{~cm}$ long, lanceolate, always entire at margins, subacute at the apices. Flowers $6.8-7.6 \mathrm{~mm}$ in diameter, spirally arranged, green to slightly green with soft pale yellow tint (Fig. 1B). Tepals 1-veined, widely spread to reflexed. Dorsal sepals 3-3.8 mm long, 1.2-1.8 mm wide, oblong ovate to ligulate, acute to obtuse at the apex. Lateral sepals $2.6-3.2 \mathrm{~cm}$ long, $0.8-1.25 \mathrm{~mm}$ wide, obliquely oblong ovate to ligulate, acute at the apices. Petals 2.8-3.2 $\mathrm{mm}$ long, $0.5-0.8 \mathrm{~mm}$ wide, very linear lanceolate $\mathrm{t}$ linear, acute to acuminate at the apices. Lip 3-3.5 mm long, 2-2.8 $\mathrm{mm}$ wide, serect, ligulate in general outline, apically dilatate, minutely serrulate at lateral margins, distally irregularly erose; lamina basal auricles overlapping the gynostemium base and by prominent, thin, ring-like rim connected with it; basal calli just near the rim, erect, geminate and fold-like; central keel convexe, longitudinal, narrowly, v-shaped to triangular, broader near lip base, reaching to the lamina apex. Gynostemium only ca. $0.1 \mathrm{~cm}$ long; column strongly abbreviated, oblique; staminodes short, slightly prominent over the column, semi-elliptic to semi-ovate, distally round, fleshy; rostellum elonagated, over two times longer then anther length, strongly prominent, spathulate, its margins thicker, somewhat finely crenulated; anther subqua-

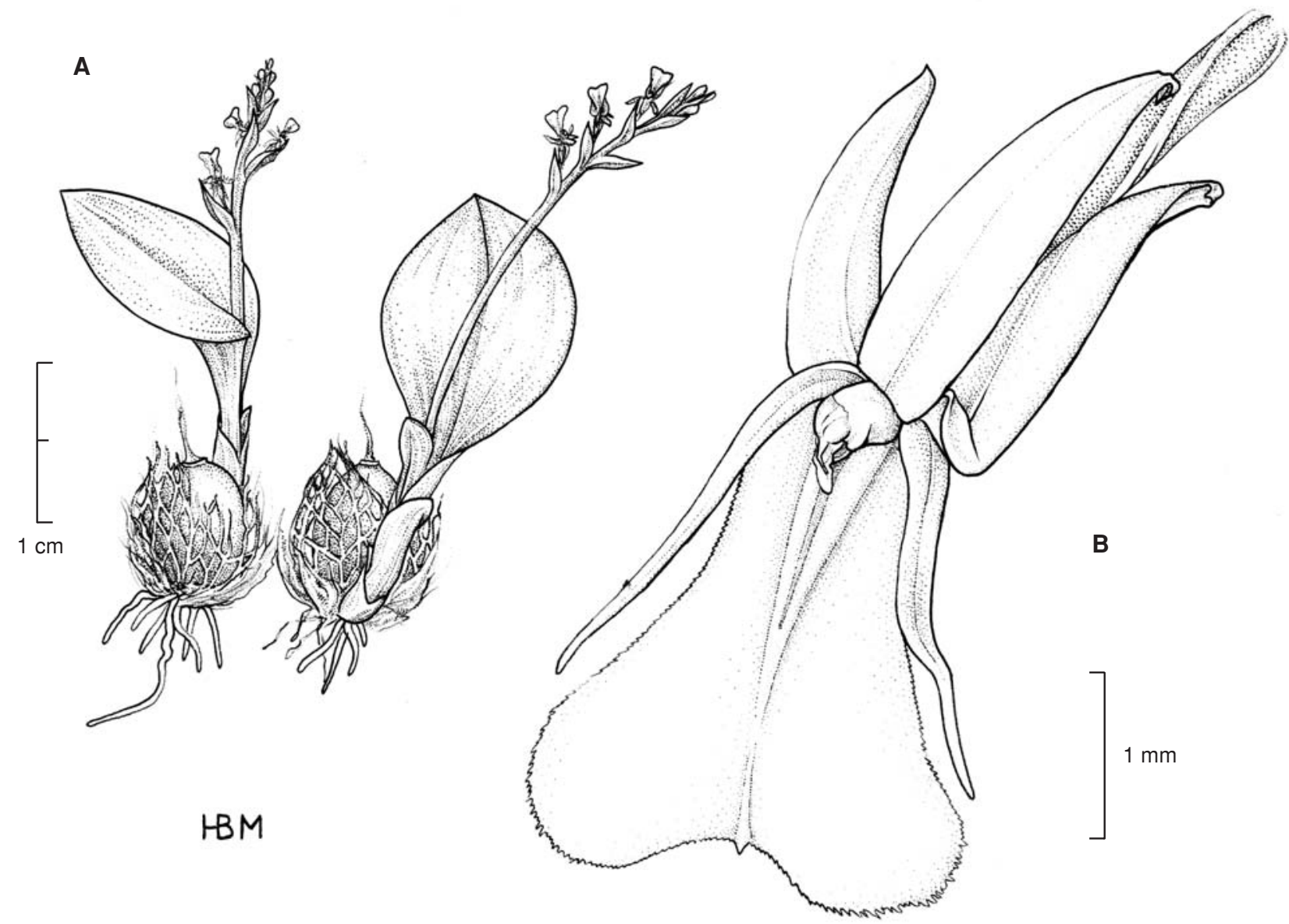

Fig. 1. Crossoliparis wendlandii: A - flowering plants; B - flower (drawing from type-specimens). 

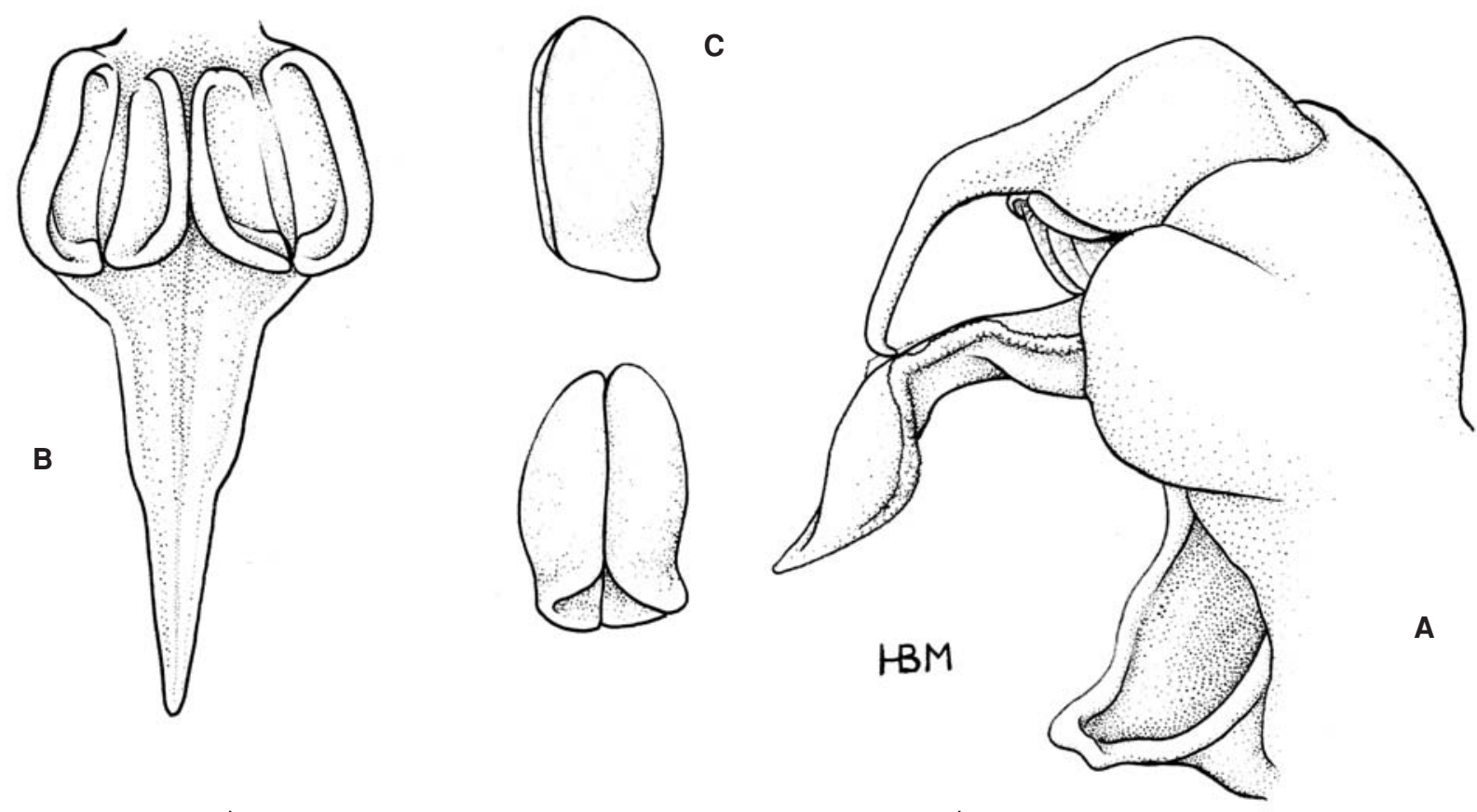

$1 \mathrm{~mm}$

Fig. 2. Gynostemium structure in genus Crossoliparis - A - side view; B - anther view from below; C - pollinia (drawing from type-specimens).

drate, movable, with narrow connection; locules opening ventrally; anther connective elongate, over two times longer then anther length, obliquely triangular; pollinia four, parallely situated to the gynostemium column, binate, obscurely equal in size and shape, oblong to semi-ellipsoid, flattened at apical part, covered only from above by anther locules and connective; stigma at prominently limbate cavity (see Fig. 2). Fruit six-ribbed, erect, capsulate, obovoid.

Etymology: An allusion to probably the closest related genera Crossoglossa and Liparis.

Note: The genus is monotypic and contains sole species Crossoliparis wendlandii (Rchb.f.) Margońska. Specific form of the species flowers, especially its gynostemium is probably effect of well know within Orchidales high selective pressure of pollinators.

Crossoliparis wendlandii (Rchb.f.) Margońska. comb. nov. Basionym: Liparis wendlandii Rchb.f., Beitr. Orch. Centr. Am. 98-99. 1866. Leptorchis wendlandii (Rchb.f.) Kuntze, Rev. Gen. Pl. 2: 673. 1891. Malaxis wendlandii (Rchb.f.) L. O. Williams, Ann. Missouri Bot. Gard. 33 (Fl. Panama, Pt. 3, 242): 136-137. 1946. Crossoglossa wendlandii (Rchb.f.) Dodson Native Ecuadorian Orchids 1: 149. 15 Nov. 1993. TYPE: Costa Rica, San Jose, "on tree", 17.07.1857, Wendland 1103 (holotype, W-R-39784!, icone AMES-100998!).

Ecology: Epiphyte; in shady and wet places; in tropical and rain forests; between mosses on tree trunks and branches. Flowering in June-July.

Distribution: Mexico, Panama, Costa Rica, Salvador, Venezuela. Alt.: 1000-2000 m.
Representative specimens: MEXICO: Guerrero, 07.1975, Hagsater 3938 (MEXU, K! icone). PANAMA: Prov. Chiriqui, Valley of the upper Rio Chiriqui Viejo, vicinity of Monte Lirio, 13-1900 m, 27.06.-13.07.1935, R.J. Seibert 195 (MO, BM-000077412!), R.J. Seibert 216 (MO, K!). COSTA RICA: sine prec. loc., (W-R!), Endres s.n. (WR-39094!).

Note: The orchids are easily recognized by e.g.: small size of plants, usually single leaf, widely indentate distall part of lip lamina, lip margins irregularly serreate, v-shaped central keel of lip lamina, abbreviated gynostemium columnm strongly enlarged and elongated rostellum and anther connective. The plants preserved collections are not very rich in American, in Europe are worse represented.

\section{ACKNOWLEDGMENTS}

I am grateful to curators and staffs of AMES, BM, K, $\mathrm{MO}, \mathrm{W}-\mathrm{R}$ for the loan of herbarium specimens and/or their hospitality during my visits. I am obliged to Prof. Dr. hab. Ryszard Ochyra for the Latinization of the diagnoses. This article was prepared thanks to Polish Ministry of Science and Higher Education, grant No. N304 029 32/1584. The studies were conducted also with using digital database Archivum Orchidalium.

\section{LITERATURE CITED}

DODSON C.H. 1993. Native Ecuadorian Orchids 1: 149. 15 Nov. 1993.

REICHENBACH H.G. 1866. Beitrage Orchideenkunde CentralAmerika's. 98-99.

WILLIAMS L.O. 1946. Ann. Missouri Bot. Gard. 33 (Fl. Panama, Pt. 3, 242): 136-137. 